Polloy, Planning, and Rosareh

WORKING PAPERS

Dovelopment Economies

Offire of the Vice President

Development Economics

The World Bank

August 1988

WPS 77

\title{
Incentive Policies and Agricultural Performance in Sub-Saharan Africa
}

Bela Balassa

It has often been said that Sub-Saharan African countries do not respond to price incentives because of rigidities and inflexibilities in their economic structure. This is not the case, however, as this paper shows. 


\section{WORKING PAPERS}

Development Economice

Exports in general, and agricultural exports in particular, are more responsive to price incentives in Sub-Saharan Africa than in developing countries as a whole. These are the resuits of an econometric investigation on the effects of real exchange rates on exports. It further appears that in Sub-Saharan Africa the impact of real exchange rates is greater on agricultural exports thar on the exports of goods and services.

Within Sub-Saharan Africa, market-oriented countries generally gained, and interventionist countries lost, export market shares as the former, but not the latter, group of countries maintained realistic exchange rates and did not appreciably bias the system of incentives against exports. The differences in policies, and in export performance, are even gredter if comparisons are made between private market economies and étatist countries in a three-fold classification scheme that puts some countries in an intermediate category.

These results are supported by the findings of a World Bank study on agricultural exports in
Eastern and Southern Africa. According to this study, industrial protection and overvalued exchange rates adversely affected the exports of the region. Another Bank study has found that in Sub-Saharan Africa agricultural growth rates were higher in countries whose currency depreciated, than in countries whose currency appreciated, in real terms.

Kenya ar 1 the Ivory Coast exemplify market-oriented, and Tanzania and Ghana interventionist, countries in Sub-Saharan Africa. Pairwise comparisons between Kenya and Tanzania and between the Ivory Coast and Ghana have indicated the superiority of the market-oriented approach in promoting exports and agricultural production.

This paper is a product of the Office of the Vice President, Development Economics. Copies are available free from the World Bank, 1818 H Street NW, Washington, DC 20433. Please contact Norma Campbell, room \$9-047, extension 33769.

The PPR Working Paper Series disseminates the findings of work under way in the Bank's Policy, Planning, and Research Complex. An objective of the series is to get these findings out quickly, even if presentations are less than fully polished. The findings, interpretations, and conclusions in these papers do not necessarily represent official policy of the Bank. 
INCENTIVE POLICIES AND AGRICULTURAL PERFORMANCE IN SUB-SAAARAN AFRICA Bela Balasa *

\section{TABLE OF CONTENTS}

Page kio.

I. The Response of Exports to Price Incentives . . . . . . . . 1

II. Alternative Policies and Export Performance . . . . . . . 6

III. Changing Export Market Shares: The Experiences of Pour

Sub-Saharan African Countries ............... 11

IV. Agricultural Policies and Performance in Tanzania and Renya . 14

V. Agricultural Policies and Performance in Ghana

and the Ivory Coast ................... 17

Conclusions ....................... 19

References ......................... 21

\section{LIST OP TABLES}

Table 1: Regression Equations for Export-Output Ratios

in Sub-Saharan African Countries . . . . . . . . . 2

Table 2: Regression Equations for Agricultural Exports

in Sub-Saharan African Countries ............. 5

Table 3: Changes in Export Market Shares in

Sub-Saharan African Countries ............... 8

Table 4: Changing Export Mariket Shares:

Tanzania, Kenya, the Ivory Coast, and Ghana ....... 12

* The author is Professor of Political Economy at the Johns Hopkins University and Consultant to the World Bank. He is indebted to Uma Lele for helpful comments and to Shigeru Akiyama for research asaistance. 
IMCBNTIVE POLICIES AND AGRICULTURAL PERPORMANCE IN SUB-SAHARAN AFRICA

\section{Bela Balassa}

This paper examines the experience of Sub-Saharan Africa with economic incentives in general, and agricultural incentives in particular, and analyzes the effect.s of these incentives on economic performance. Section I of the paper reports on the findings of an econometric investigation on the responsiveness of exports to incentives. Section II reviews changes in the export market shares of Sub-Saharan African countries pursuing different development strategies. Section III examines changes in export market shares for four Sub-Saharan African countries, Tanzania, Renya, Ghana, and the Ivory Coast. Sections IV and V provide a comparative analysis of agricultural policies and performance in two pair of these countries: Tanzania and Kenya (Section IV) and Ghana and the Ivory Coast (Section V).

\section{The Response of Exports to Price Incentives}

Table 1 reports the results of estimates for the exports of goods and services and for merchandise exports, obtained by the use of a reduced form equilbrium equation, for 16 sub-Saharan African countries. I/ The estimates pertain to the 1965-82 period and to the 1965-73 and the 1974-8̂2 subperiods.

The real exchange rate variable has the expected sign and it is statistically significant at the 1 percent level in the equations for the 1974-82 subperiod and the entire 1965-82 period but not for the 1965-73 subperiod. In the latter case, the regression coefficient is significant at

1/ The underlying model, and the derivation of the equation, are presented in Balassa, 1988. 
Table 1

Regression Equations for Export-Output Ratios in Sub-Saharan African Countries (t-values in parenthesis)

Constent Reel Excilange Rote Forelgn Incoms $N$ F $R^{2}$

1. 1965-73
(a) exports of goods and
nonfactor sorvicos
$-0.05$
0.37
$(-0,87)$
$(1.97)^{+}$
1.21
(1.07)
(b) merchandise exports
$-0.14$
0.27
$(-1.77)^{4}$
(1.04)
3.39
(2.17)"
$128 \quad 2.43 \quad 0.022$
$\begin{array}{lll}128 & 2.81 \quad 0.028\end{array}$

11, 1974-82
(a) exports of goods and
$-0.02$
0.78
$(6.60)^{*-1}$
0.95
(1.45)
$\begin{array}{lll}128 & 24.44 & 0.270\end{array}$
(b) merchendise exports
-0.02
$(-0.65)$
0.91
$(4.07)^{* * *}$
1.79
(1.46)
$\begin{array}{lll}128 & 10.28 & 0.127\end{array}$

111. 1965-82
(a) exports of goods and
0.01
$(0.76)$
0.88
$(8.49)^{* 11}$
0.04
$(0,08)$
$\begin{array}{lll}272 & 36.98 & 0.210\end{array}$
nonf actor services
0.02
(0.54)
1.01
$(5.93)^{* 1 *}$
0.52
$(0.71)$
$\begin{array}{lll}272 & 18.83 & 0.116\end{array}$
(b) werchendise exports

-

Source World Bank data base

Note: (a) The varlables have been expressed in terms of rates of change between successive years for individual countries combining time-series and cross-section observations.

(b) Levels of statistical significance: + 10\%; $5 \%$; * 18 . 
the 10 percent level for the exports of goods and services and does not reach this level of significance for goods alone.

Limiting attention to the values taken by the regression coefficienta which have a high level of statistical significance, we find that the coefficients vary between 0.78 and 1.01 . Since the variables have been expressed in terms of rates of change, this means that a one percent change in the exchange rate is associated with a four-fifth to one percent change in the ratio of exports to output.

The coefficients for the real exchange rate variable are uniformly higher for the Sub-Saharan African countries than for all developing countries, for which estimates are presented in Balassa, 1988. For the 197482 subperiod and for the entire 1965-82 period, respectively, the differences between the two sets of estimates are 0.13 and 0.24 percentage points for merchandise exports and 0.20 and 0.40 percentage points for the exports of goods and services.

The results conflict with popular notions, according to which changes in the real exchange rate would have less of an effect on the exports of subSaharan African countries than in countries at higher levels of development. But, they are consistent with the observation that African countries, which let their exchange rate become greatly overvalued, experienced considerable losses in export market shares (Sections IV and V).

In contradistinction with the case of all developing countries, however, the level of significance of the foreign income variable is very low; it reaches 5 percent only in the case of merchandise exports in the 1965-73 period. This result may be explained by the high share in Sub-Saharan exports of foods, wie exportation of which responds little to income changes in the 
developed countries. Also, coffee exports, accounting for a large proportion of the exports of severai Sub-Saharan African countries, are determined by quotas under the International Coffee Agreement, which bear little relationship to changes in incomes in the developed countries.

Comparable estimates have been made fo: agriculture. The reaults again show the responsiveness of exports to changes in the real exchange rate. The regression coefficients for the export-output ratio range between 1.08 and 1.35; they are statistically significant at the 1 percent level for the 1974-82 subperiod and the entire 1965-82 period and at the 10 percent level for the 1965-73 subperiod.

As in the case of merchandise exports, the regression coefficients of the real exchange rate variable for agricultural exports are uniformly higher for the Sub-Saharan African countries than for all developing countries. 1/ In fact, the differences are larger in the present case, ranging from one-half for the 1974-82 subperiod to a near doubling in the 1965-73 subperiod and the entire 1965-82 period.

At the same time, for the countries of Sub-Saharan Africa, the regression coefficients for agriculture are substantially higher than for merchandise or for goods and services. This result again conflicts with conventional wisdom, which holda that agricultural exports are less responsive to prices than industrial exports.

1/ The results for the developing countries are shown in Balassa, 1988. 
Table 2

Rerression Equations for Agricultural Exports in Sub-Seharan African Countries

Constant Real Exchenge Rate Forelgn Income $N$ F $R^{2}$

- xport-output Ratio

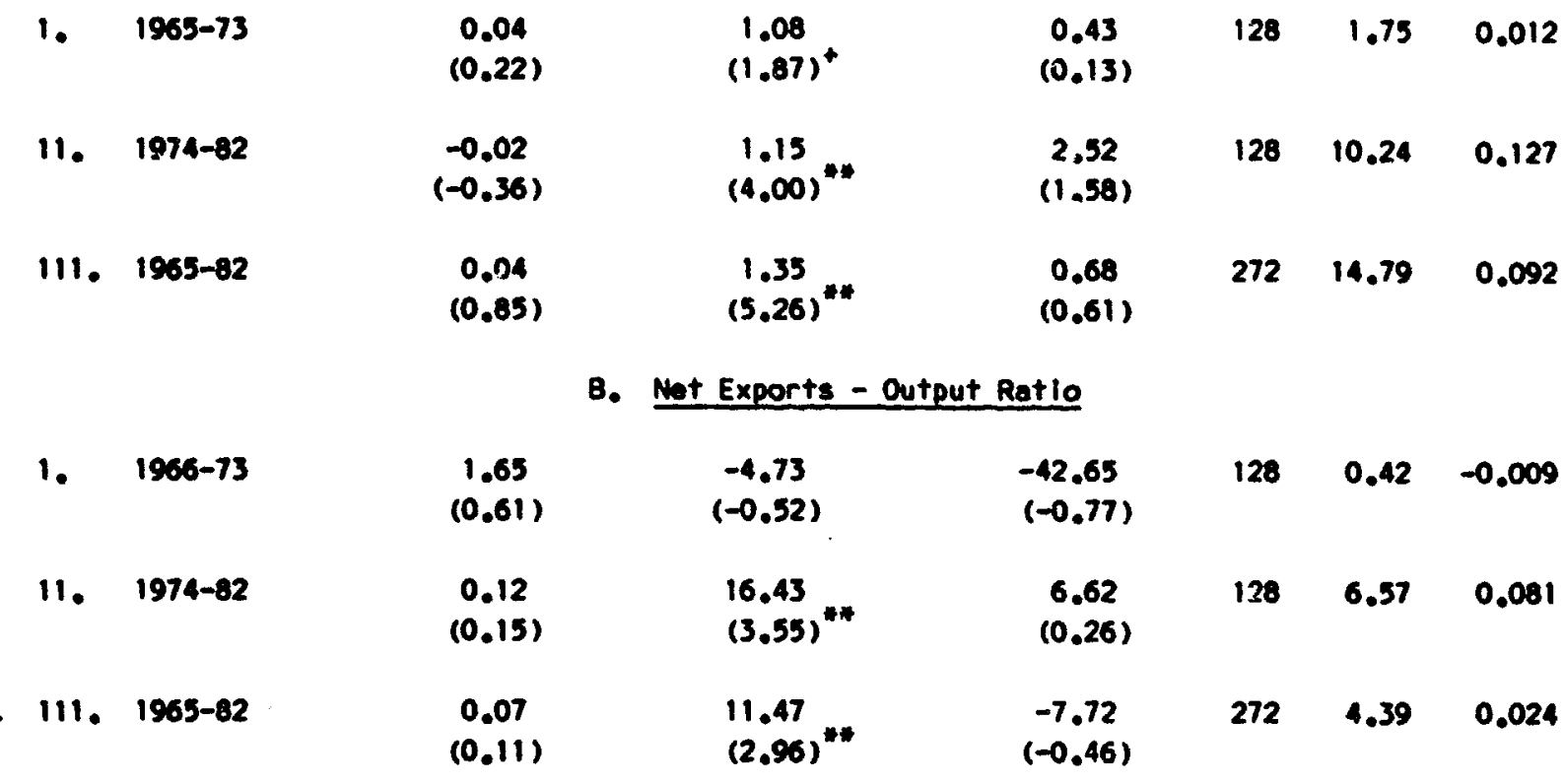

Notes: See Table 1 
In turn, the statistical significance of the foreign income variable does not even reach the 10 percent level for the countries of Sub-Saharan Africa. This reault may be explained by reference to the low income elasticity of demand for foodstuffs and, in particular, for tropical beverages as noted above in conjunction with merchandise exports.

The coefficient of determination is lower for agricultural exports than for merchandise exports or for the exports of goods and services. The differences in the results may be explained by non-price factors which affect agricultural production. I/ Nevertheless, apart from the 1965-73 period, the Y-gtatistics are high.

The adjusted $R^{2}$ s and the P-statistics are substantially lower in the equation utilizing the net export ratio as the dependent variable. This result may be explained in part by the fact that errors in the export and the import data are amplified when one takes the difference between the two and in part by the effects on imports of changes in foreign exchange receipts and in the availability of food aid.

In the net export equation, the real exchange rate variable is statistically significant at the 1 percent level in the second subperiod as well as in the entire period. It takes values of 16.4 in 1974-82 and 11.5 in 1965-82. The results again provide evidence of the effects of changes in the real exchange rate on trade in agricultural products.

\section{Alternative Policies and Export Performance}

In this section of the paper, we analyre the effects of policy choices on export performance in the case of merchandise exports and 
agricultural exports. In so doing, alternative classification schemes have been used in regard to the policies applied by the countries of sub-Saharan Africa.

Distinction has first been made between market-oriented and interventionist countries on the basis of available information on the extent of public interventions in capital, labor, and foreign exchange markets. The first group includes Botswana, Cameroon, Ivory Coast, Kenya, Malawi, Mauritius, Niger, Togo, and Upper Volta while the second comprises Benin, Ethiopia, Ghana, Madagascar, Mali, Senegal, Sudan, Tanzania, Zaire, and Zambia. A three-fold classification scheme has also been utilized, with Botswana, Cameroon, Ivory Coast and Mauritius included in the group of private market economies, Benin, Bthiopia, Chana, Madagascar, Mali, Tanzania and Zambia in the group of etatist countries, and Renya, Malawi, Miger, Senegal, Sudan, Togo, Upper Volta, and zaire in an intermediate group.

The policies applied greatly affected export performance in the countries under consideration. This is evidenced by changes in export market shares for each country's merchandise exports as well as for its agricultural exports. The results reported in Table 3 show the ratio of average export market shares in the 1974-78 period to the average for the 1971-73 base period.

The range of increases in average export shares was between 9 to 81 percent in market economies, except for Cameroon, Niger, and Togo that experienced declines of 4 to 22 percent. In turn, interventionist countries gonerally lost export market shares, with the losses exceeding one-fourth in Benin, Ethiopia, Ghana, and Tanzania, where policy-induced distortions -- in particular, the overvaluation of the exchange rate -- were the most 
Table 3

Changes in Export Market Shares in Sub-Saherau African Cr u'dtrieg

\section{Country}

Botswana

Cameroon

Ivory Coast

Maritius

Kenya

Malewi

Niger

Togo

Upper volta

Senega:

Sudan

Zaire

Benin

Ethiopia

Ghana

Madagascar

Mali

Tanzania

Zambia

\section{Merchandise Exports}

1974-78

181.2

96.0

118.9

108.1

109.0

152.3

77.8

91.4

121.9

103.2

83.6

76.9

41.8

60.2

72.8

82.4

106.6

71.4

87.4

\section{Traditional Agricultural Exports} 1974-78

120.7

107.7

134.9

89.1

123.8

150.1

47.1

61.6

102.0

119.3

90.3

63.1

35.8

60.2

79.7

88.9

89.1

99.4

Source: World Bank data tapes.

Note: The results show the ratio of a country's export market share in 197478 to its share in $1971-73$.

The average ratio for merchandise exports has been derived as the weighted average of the ratios calculated for traditional primary exports, defined as accounting for more than 1.5 percent in total exports in 1971-73, taken individually for nontraditional primary exports, for fuel exporss, and for manufactured exports. For traditional agricultural exports, the average pertains to agricultural products within the traditional primary export group. 
pronounced. imong the interventionist countries, only Mali and Senegal experienced small gains (13 to 7 percent) in export market shares.

The effects of the policies applied on export performance are also apparent in weighted averages calculated for the various groups. Thus, market-oriented countries had an average gain of 5 percent and interventionist countries an average loss of 19 percent in export market shares during the 1974-78 period. Using a three-fold classification scheme, and distinguishing among private market economies, intermediate, and étatist countries, the corresponding figures are $+15,-10$, and -24 percent (Balassa, i984).

Table 3 further provides information on the performance of individual countries in regard to traditional agricultural exports, defined as accounting for at least 1.5 percent of expo:t value in 1971-73. The results confirm the findings pertaining to total merchandise exports.

Apart from Mauritius, Niger, and Togo, private market economies in Sub-Saharan Africa increased their market shares of traditional agricultural exports; the largest gains were observed in Malawi (50 percent), the Ivory Coast (35 percent), Renya (25 percent), and Botswana ( 21 percent). In turn, apart from Senegal, all interventionist countries lost export market shares, with a nearly two-thirds $108 s$ in the case of Benin and over one-third in Ethiopia and zaire. As shown in Table 3, the differences are even more pronounced if private market economies and étatist countries are compared.

All i= all, market-oriented countries generally gained, and interventionist economies lost, export market shares during the 1973-78 period, when the former group of countries did not appreciably discriminate against exports and adopted realistic exchange rates while the latter group strongly biased the system of incentives against exports and let their 
exchenge rate appreciate in real terms. The differences in policies, and in export performance, are even greater if comparisons are made between private market economies and etatist countries in three-fold classification scheme that puts some countries in an intermediate group. 1/

Thes: results are supported by the findings of a World Bank study on agricultural exports in Bastern and Southern Africa. According to the study, industrial protection and overvalued exchange rates adversely affected agricultural exports in this regioa during the 1965-83 period (Gulhati, Bose, and Atukorala, 1985).

Another Bank study found that, in Sub-Saharan Africa, countries with a high degree of price discrimination egainst agriculture had an average agricultural growth rate of 0.8 percent in the 1970-81 period while the corresponding growth rates were 1.8 percent and 2.9 percent in countries with medium and low price discrimination against agriculture (Cleaver,, 1985). This result was confirmed by an econometric analysis of the relationship between the extent of price distortions and agricultural output growth in these countries (Ibid) although the small number of observations limits the validity of the results.

The same author examined the implications of overvalued exciange rates for the growth of agricultural production in Sub-Saharan Africa. He found that, on the average, agricultural growth rates were higher in countries whose currency depreciated, than in countries whose currency appreciated, in real terms. In the 1970-81 period, the average annual growth rate of

I/ For a detailed discussion of the classification scheme utilized and the empirical results obtained, see Bele Balassa (1984). 
agricultural production was 2.6 percent in the firat group and 1.5 percent in the second (Ibid).

III. Changing Bxport Market Shares: The Experiences of Four Sub-Saharan African Countries

Table 4 reports estimates on changes in export market shares for Tanzania, Renya, Ghana, and the Ivory Coast for the 1974-78 and the 1979-81 periods. Changes in market shares have been expressed as the ratio of actual exports to hypothetical export3, calculated on the assumption that the country maintained its share in world markets in the 1971-73 and 1976-78 base periods, respectively.

Table 4 provides information on the traditional agricultural exports of the four countries, defined as accounting for at least 1.5 percent of their total merchandise exports in the base period. The table also shows weighted averages for these exports, the weights being each country's base period export values. Information is further provided on nontraditional primary exports, defined as primary products that individually accounted for less than 1.5 percent of total exports in the base period, which in their great bulk are agricultural commodities. Finally, the average for total merchandise exports has been calculated from data for traditional agricultural and nonagricultural primary exports, $1 /$ nontraditional primary exports, fuel exports, and manufactured exports.

The data show a 1 percent average decrease in Tanzania's market shares in its traditional agricultural exports in 1974-78, followed by a 19 percent decline in 1979-81. This contrasts with increases of 24 percent and 19 percent in Kenya in the two periods, respectively.

1/ Tanzania and Kenya did not have any traditional nonagricultural exports; this category includes sawn and veneer logs in the Ivory Coast and Ghana, sawn wood in the Ivory Coast, and sawn wood and aluminum in Ghana. 
Table 4

Changing Export Morket Shares: Tanzania, Kenya, the Ivory Coast, and Ghana

Tanzania Kenye Ivory Cost Ghana

$1974-78$ 1979-81 1974-78 1979-81 1974-78 1979-81 1974-78

\begin{tabular}{|c|c|c|c|c|c|c|c|}
\hline Morchand lse Exports & 71.4 & 59.8 & 109.0 & 101.2 & 118.9 & 125.4 & 72.8 \\
\hline Nontraditional Primary Exports & 56.4 & 60.0 & 96.0 & 108.0 & 116.1 & 214.8 & 76.2 \\
\hline Iraditional ngricuitural Exports & 99.4 & 8.1 & 123.8 & & 134.9 & 132.4 & 79.9 \\
\hline Coffee & 104.9 & 94.6 & 130.5 & 121.2 & 140.1 & 109.1 & \\
\hline Tea & 119.1 & 128.1 & 123.2 & 143.5 & & & \\
\hline Cotton & 82.7 & 57.7 & & & 125.2 & 203.3 & \\
\hline Sisal & 101.2 & 95.0 & 215.7 & 204.1 & & & \\
\hline Ol Isend Cako & 57.7 & 33.7 & & & & & \\
\hline Tobaceo & 146.6 & 101.3 & & & & & \\
\hline Mat, proparad & & & 92.0 & 23.9 & & & \\
\hline Malze & & & 53.3 & 24.4 & & & \\
\hline Cocoa Brans & & & & & 139.4 & 205.1 & 81.1 \\
\hline Cocos Paste & & & & & 87.1 & 39.7 & \\
\hline Cocos Butter & & & & & 127.7 & 126.5 & 66.9 \\
\hline Bananas & & & & & 89.6 & 72.9 & \\
\hline Palm oll & & & & & 141.2 & 63.3 & \\
\hline
\end{tabular}

Source: World Bank data base.

Note: The results show the ratio of a country's export market share in the pariod under consideration to Its share in the base perlod. For 1974-78 the base period In 1971-73; for 1979-81, it is 1976-78. On the mathod of calculating changes in arket shares for merchandise exports, see Table 2. 
Losses in market shares in Tanzania were much larger for annual crops than for tree crops (coffee and tea). The only major annual crop where Tanzania made gains in export market shares, tobacco, reached only one-half of its production target, despite large injections of capital. Among minor exports, cashew nuts and pyrethreum experienced a decline by two-thirds from peak levels (B1Lis, 1985). In the exportation of crifee and tea, as well as in that of agava fiber, where the two sountries are in competition, Renya's export performance was much superior to that of Tanzania. The differences between the two countries are even greater in regard to nontraditional primary exports. While in Kenya average $1088 e$ of 4 percent in 1974-78 gave place to a gain of 8 percent in 1979-81, Tanzania experienced 10sses of 44 percent in the first and 40 percent in the second period.

Tanzania also did less well than Kenya in the exportation of manufactured goods. As a result, Tanzania's average market share in merchandise exports fell by 29 percent in 1974-78, followed by a decline of 60 percent in 1979-81. Average gains for Kenya were 9 percent in the first period and 1 percent in the second, when it lost manufactured exports due largely to the closing of the Tanzanian border.

Among its traditional agricultural exports, data for 1974-78 period show average $108 s e s$ in export market shares of 19 percent in cocoa beans and 33 percent in cocoa butter for Ghana. Ghana experienced even larger 10 ses in its market shares in traditional nonagricultural exports and in nontraditional primary exports, bringing the decline in its average market share in merchandise exports to 27 percent. While there are no comparable data for the 1978-81 period, available information points to the continuation of these trends. 
By contrast, the Ivory Coast increased its export market shares in cocoa butter and cocoa paste by 39 percent and 27 percent, respectively, in the 1974-78 period. And, while the two countries have similar climatic conditions, the Ivory Coast diversified its agricultural exports during the 1960s and made gains in the subsequent period in cotton and palm oil, although not in bananas.

Taken together, the Ivory Coast had an average gain of 35 percent in its traditional agricultural exports in 1974-78, compared with a 1088 of 20 percent for Ghana. The Ivory Coast also increased its market shares in nontraditional primary exports by 16 percent, compared with a 1088 of 24 percent for Ghana. And, the Ivory Coast made further gains in this commodity group in 1979-81, bringing the average gain for all merchandise exports to 25 percent, exceeding the 19 percent gain in 1974-78. In turn, Ghana experienced a 27 percent 108 in merchandise exports in 1974-78; data for 1979-81 are not available.

IV. Agricultural Policies and Performance in Tanzania and Kenya 1 -

An important factor contributing to 1088 s in export market shares in Tanzania was the increasing overvaluation of the real exchange rate. Thus, Renneth Meyers has estimated that the ratio of exports to agricultural value added in Tanzania would have been 18 percent higher in 1982 if the exchange rate remained at its 1973 level in real terns. Yet, the appreciation of the real exchange rate by 44 percent in the 1973-82 period followed an appreciation of 32 percent between 1965 and 1973.

1/ Unless otherwise noted, the data originate in Meyers 1985a and 1985b. 
Changes in the reai exchange rate do not fully reflect the adverse effects of the incentive system on agricultural exports, which contributed to the decline in the ratio of exports to agricultural value added in Tanzania from 41 percent in 1973 to 14 percent in 1982. Other important influences were the increase in marketing margins of the parastatals that led to reductions in the ratio of producer to border prices, in particular for coffee and tea; increasing shortages of agricultural inputs, machinery spares, and consumstr goods; and the deterioration of transport facilities (Lele, 1984).

Exports were further discouraged as the prices of export crops declined by one-third, compared with the prices of domestic crops, between 1969-70 and 1979-80 in smallholder production. Yet, the average real price of domeutic crops, derived by deflating the index of producer prices by the consumer price index, also decreased by 16 percent between 1970 and 1980 (E11is, 1985).

The adverse changes in the incentive system led to a fall of Tanzania's agricultural exports by 6.5 percent a year between 1970 and 1981. In turn, among domestic crops, marketed production declined at an average annual rate of 20.8 percent in the case of rice and 3.8 percent for wheat in the 1970-82 period. Also, while average increases were 3.6 percent a year for maize, production in 1981 and 1982 did not reach one-half of the peaks attained in 1978 and 1979.

At the same time, although it has been claimed that sales in informal markets rose rapidly in Tanzania, increases in imports indicate that domestic production was less and less able to provide for the needs of the population. Thus, the combined imports of maize, rice, and wheat were 388 
thousand tons in 1981-82, compared with 13 thousand tons in 1970-71 (Lele, 1988, p. 168 ).

In Renya, the ratio of agricultural exports to value added was 33 percent in 1973 and 31 percent in 1982. The relative constancy of this share may be largely attributed to the constancy of the real exchange rate and the lack of discrimination againgt exports in the agricultural sector. Thus, prices for export crops and domestic crops moved in a parallel fashion during the period; nor was there much variation among domestic crops. Also, the averag real price of both export and domestic crops increased by 13 percent between 1972-73 and 1982-83 (Jabara, 1985).

The system of incentives applied may explain that Kenyan agricultural exports rose by 2.6 percent a year between 1970 and 1981 . In turn, marketed production increased at average annual rates of 2.3 percent in the case of maize, 2.1 percent in the case of rice, and 1.7 percent in the case of wheat (Lele et al, 1985).

The situation is even more favorable if all domestic crops rather than only staple cereals are considered. Between 1972/73 and 1982/83, the production of domestic crops rose by 137 percent while the increase for all crops was 126 percent (Jabara, 1985).

Taking $1979 / 80$ as the terminal year, comparisons may further be made with Tanzania. Between $1972 / 73$ and $1979 / 80$, the production of export crops rose by 18 percent and that of domestic crops by 104 percent in Renya, with an average increase of 95 percent. In turn, between 1973/74 and 1979/80, the 23 percent decline in the production of export crops in Tanzania was barely compensated by the $r$ ise in the production of domestic crops, with an average increase of 8 percent (B11is, 1985 and Jabara, 1985). 
V Agricultural Policies and Performance in Ghana and the Ivory Coast $1 /$

Changes in export market shares in Ghana and the Ivory coast represent a continuation of trends since independence. Between $1963 / 64$ and 1979/80, cocoa production fell from 443 to 275 thousand metric tons in Ghana while it increased from 99 to 379 thousand metric tons in the Ivory Coast. And, in Ghana, a further decline to 107 thousand metric tons occurred by 198384 (Stryker and Brandt, 1983).

The results may be explained by reference to the price policies applied in the two countries. In 1984, Ghanaian cocoa farmers received 20 percent of the world market price while the corresponding ratio was 84 percent in the Ivory Coast (Ibid). Although the resulto for Ghana represent a deterioration of the situation from earlier periods, high taxes were levied on cocos from the early 1960s onwards.

Relatively high producer prices provided incentives in the Ivory Coast for the expansion of cultivation, the upgrading of varieties through replanting, and the careful husbanding of cocoa trees. In turn, in Ghana, a number of existing plantations were abandoned and new high-yielding cocoa varieties were not introduced in cases when replanting did occur.

Hor did Ghana experience a diversification of exports, so that the decline in the exports of cocoa was not compensated by increases in other agricultural exports. In fact, between 1970 and 1982 , the ratio 'of exports to agricultural value added fell from 32 to 2 percent.

High industrial protection and the increasing overvaluation of the exchange rate contributed to these results. Thus, between 1975 and 1982 , the real exchange rate appreciated by 80 percent in Ghana.

1/ Unless otherwise noted, the data originate in Sherbourne $1985 a$ and $1985 \mathrm{~b}$. 
Import-substitution crops, in parcicular cereals, produced mainly on large farms, were protected by quantitative import restrictions. These crops, however, are at a comparative disadvantage in Ghana. Also, they suffered the consequences of the deterioration of physical infrastructure, in particular transportation facilities, and the scarcity of imported inputs, such as fertilizers and insecticides. Thus, the production of cereals declined by 62 percent between 1970 and 1983 while the production of starch staples fell by 40 percent.

These figures indicate the adverse effects of the policies applied on Ghanaian agriculture. While the intention had been to syphon off revenues from cocos production to the benefit of other sectors of the economy, foreign exchange earnings decreased as a result, eventually leading to a decline in other production activities that were unable to obtain the necessary inputs.

By contrast, the Ivory Coast adopted a balanced system of incentives while encouraging the inflow of foreign capital and the immigration of labor from neighboring countries. As a result, agricultural production continued to rise at a rapid rate, with average increases of 3.8 percent in value added between 1970 and 1980. Within agriculture, the production of domestic crops and export crops grew in a parallel fashion, maintaining the share of exports at about three-fourths of the total.

With value added in manufacturing rising by 8.2 percent a year, the gross domestic product of the Ivory Coast increased at an average annual. rate of 6.4 percent between 1970 and 1980 , following a growth rate of 8.0 percent between 1960 and 1970. By contrast, increases of 2.2 percent a year in the $1960 \mathrm{~s}$ gave place to an average annual decline of 0.5 percent in the $1970 \mathrm{~s}$ in Ghana. Measured in terms of purchasing power parities, per capita incomes 
increased from $\$ 779$ in 1960 to $\$ 1410$ two decades later in the Ivory Coast while a decline from $\$ 1009$ to $\$ 762$ occurred in Ghana (Summers and Heston, 1984).

Policy performance deteriorated in the Ivory Coast towards the end of the $1970 \mathrm{~s}$ as high-cost investments were undertaken, in particular in sugar, and the exchange rate became increasingly overvalued as domestic inflation accelerated while the parity vis-a-vis the Erench franc was maintained in the framework of the Franc area. Important policy ceforms were introduced in subsequent years, however, which are expected to lead to the resumption of rapid economic growth.

In Ghana, the Bconomic Recovery Program was launched in April 1983, involving a devaluation of the currency by 1900 persent, and the adoption of a flexible exchange rate system. Also, producer prices have been raised to a considerable extent. However, in the pursuit of self-sufficiency, the incentive system continues to favor import-substitution crops and further increases in cocoa prices would be necessary for the full exploitation of Ghans's production potential.

Conclusions

This paper has provided evidence or the effects of the policies applied on economic performance in Sub-Saharan Africa, with emphasis given to agriculture. It has been shown that exports in general, and agricultural exports in particular, are highly responsive to changes in the real exchange rate. In fact, exports are more responsive to price incentives in Sub-Saharan Africa than in developing countries in general.

It has further been shown that market-oriented countries generally gained, and interventionist countries lost, export market shares as the former, but not the latter, group of countries maintained realistic exchange 
rates and did not appreciably bias the system of incentives against exports. The differences in policies, and in export performance, are even greater if comparisons are made between private market economies and étatist countries in a three-fold classification scheme that puts some countries in an intermediate group.

Kenya and the Ivory Coast exemplify market-oriented, and Tanzania and Ghana interventionist, countries in Sub-Saharan Africa. The paper has made pair-wise comparisons between Kenya and Tanzania and between the Ivory Coast and Ghana, indicating the superiority of the market-oriented approach in promoting exports and agricultural production. 


\section{REFERENCES}

Balassa, Bela, "Adjustment Policies and Development Strategies in Sub-Saharan Africa, 1973-78," Moise Syrquin, Lance Taylor, and Larry B. Westphal, eds., Economic Strategy and Performance, Essays in Honor of Hollis B. Chenery, New York, Academic Press, 1984, Pp. 317-40.

Balassa, Bela, "Economic Incentives and Agricultural Exports in Developing Countries," presented at the Eighth Congress of the International Economic Association held in New Delhi, India in December 1986. To be published in the Proceedings of the Congress (cited as Balassa, 1988).

Cleaver, Kevin M., "The Impact of Price and Exchange Rate Policies in Agriculture in Sub-Saharan Africa," World Bank Staff Working Paper No. 728, Washington, D.C., World Bank, 1985.

E11is, Brank, "Agricultural Price Policy in Tanzania," World Development, May 1985.

Gulhati, Ravi, Bose Swadesh, and Vimal Atukorala, "Exchange Rate Policies, in Bastern and Southern Africa, 1965-1983," World Bank Staff Working Paper No. 720, Washington, D.C. World Bank, 1985.

Jabara, Cathy L., "Agricultural Pricing Policy in Kenya," Norld Development, May 1985, pp. 611-26.

Lele, Uma, "Tanzania: Phoenix or Icarus?" in Arnold C. Harberger, ed. World Economic Growth, San Francisco, Institute for Contemporary Studies, 1984, PP. 159-96.

Lele, Uma, "The Role of Price and Non-Price Pactors in Explaining Sources of Growth in East African Agriculture: Some Lessons for Governments and Donors," Washington, D.C., World Bank, January 1988 (mimeo).

Meyers, Renneth, "Agricultural Policy and Performance in Tanzania," Washington, D.C., Horld Bank, September 1986 (mimeo) cited as 1986a.

Megers, Kenneth, "Agricultural Policy and Performance in Kenya," Mashington, D.C., World Bank, September 1985 (mimeo); cited as 1985b.

Sherbourne, Lynn, "Agricultural Policy and Performance in Chana," Washington, D.C., World Bank, September 1985 (mimeo); cited as 1985a.

Sherbourne, Lynn, "Agricultural Policy and Performance in the Ivory Coast," Washington, D.C., World Bank, September 1985 (mimeo); cited as 1985b.

Stryker, J. Dirck and Lewis E. Brandt, "Price Policy in Africa," Washington, D.C. Associates for International Resources and Development, September 1985 (mimeo). 
Summers, Robert and Alan Heston, "Improved International Comparisons of Real Product and It Composition, 1950-80," Review of Income and Wealth, June 1984, Pp. 207-62. 


\section{Title}

WPS43 Tax Administrotion in Developing

Countries: Strategles and Tools

of Implementation

WPS44 The Size and Growth of Government

Expenditures

WPS45- Assigned to WDR

WPS60

WPS61 Student Performance and Schools costs in the Philippines' High Schools

WPS62 Status of Universities in the Arab Countries of it. Middle East and North Africa

WPS63

Does Japan Import Less Than It Should?

WPS64 Cocoa and Coffee Pricing Policies

in cote d'Ivoire

Health and Family Planning Programs

WPS66 Slowing the Stork: Better Health for Women through Family Planning

WPS67 Price and Tax Policy for SemiSubsistence Agriculture in Ethiopia

WPS68 A Comparison of Lanps for Domestic Lighting in Developing Countries

WPS69 Does Local Financing Make Public Primary Schools More Efficient?

The Philippine Case
Author

Date

Contact

Tax Administration

Division

David L. Lindaver

Emmanuel Jimenez

$V$ icente Paqueo

August 1988

T. Hawkins

33678
Takamasa Aki yama

Howard Barnum

George 1. Za'rour

Kenji Takeuchi

July 1988

J. Epps

33710

Anthony R. Measham

Roger W. Rochat

Robert D. Weaver

Saad Ali Shire

Robert van der Plas

Emmanual Jimenez

Vicente Paqueo

Ma. Lourdes de Vera
August 1988

T. Hawkins

33678
August 1988

July 1988

July 1988
S. Ainsworth 31091

A. Manciano 33226

D. Gustafson 33714
D. Gustafson 33714

August 1988 
Titie

WPS70 Vocational Education and the Economic

Environment: Conflict or

Convergence?

WPS71 School Effects on Student Achievement in Nigeria and Swaziland

WPS72 The Relative Efficiency of Public Schools in Developing Countries

WPS73 Taxation and Output Growth: Evidence from African Countries

Jonathan Skinner

WPS74 Fiscal Stabilization and Exchange Rate Instability: A Theoretical Approach and Some Policy Conclusions Using Mexican Data

WPS75 Welfare Dominance and the Design of Excise Taxation in the cote d'Ivoire

WPS76 On the Shadow Price of a Tax Inspector

WPS77 Incentive Policies and Agricultural

Performance in Sub-Saharan Africa

WPS78 Economists, Institutions and Trade

Restrictions: A Review Article

WPS79 Quantitative Appraisal of Adjustment Lending
Arvil V. Adams

Antoine Schwartz

Marlaine Lockheed

Andre Komenan

August 1988

T. Hawk ins

33678

Emmanuel Jimenez

August 1988

T. Hawkins 33678
Shlomo Yitzhakl

Yitzhak Vakneen

Andrew Feltenstein

Stephen Morris

Shlomo Yitzhaki

Wayne Thirsk

Bela Balassa

J. Michael Finger

Bela Balassa
August 1988

August 1988

A. Bhalla 60359

A. Bhalla 60359

August 1988

N. Campbel I 33769

August 1988
N. Campbel I 33769 